\title{
PENINGKATAN KEMAMPUAN SUMBER DAYA MANUSIA APARATUR DI KABUPATEN SERANG
}

\author{
IMPROVED ABILITY OF HUMAN RESOURCES APPARATUS \\ IN THE DISTRICT SERANG
}

\author{
Tini Apriani \\ Badan Penelitian dan Pengembangan (BPP) Kementerian Dalam Negeri \\ Jl. Kramat Raya No. 132 Senen, Jakarta \\ No. Telp.: +62 213101955 \\ Email : tiniapriani@yahoo.com \\ Dikirim: 4 Juli 2014 Direvisi: 12 Agustus 2015 Disetujui: 26 Oktober 2015
}

\begin{abstract}
Abstrak
Diterapkannya sistem desentralisasi memberikan kewenangan yang besar pada daerah untuk mengembangkan kapasitas pemerintah daerah dalam penyelenggaraan urusan pemerintahan melalui pengembangan kapasitas sumber daya manusia aparatur. Namun demikian, selama kurang lebih satu dasawarsa terakhir, upaya ini masih belum optimal guna mencapai hasil yang diharapkan. Kajian ini dilakukan untuk memotret pengembangan kapasitas sumber daya manusia aparatur di Kabupaten Serang, dilaksanakan pada tahun 2012. Metode pendekatan yang digunakan adalah deskriptif kualitatif, dengan penggunaan data primer dan sekunder. Hasil kajian menunjukkan kualitas sumberdaya manusia masih rendah, banyak jabatan struktural yang belum terisi, rekrutmen belum didasarkan pada analisis jabatan, evaluasi jabatan belum dilakukan, penilaian kinerja individu berdasarkan kompetensi belum dilakukan, serta sebagian besar pegawai belum mendapatkan diklat sesuai dengan jabatannya. Disarankan untuk melakukan penataan sistem rekrutmen; analisis jabatan; evaluasi jabatan; penyusunan standar kompetensi jabatan; penilaian individu berdasarkan kompetensi; pengembangan database pegawai; dan perbaikan kurikulum pendidikan dan pelatihan.
\end{abstract}

Kata kunci: Sumber Daya Manusia, Pengembangan, Kapasitas.

\begin{abstract}
Implementation of a decentralized system gives great authority to the regions to develop the capacity of local governments in the implementation of government affairs through the development of human resource capacity of the apparatus. However, for more than a decade, these efforts are still not optimal to achieve the expected results. This study was conducted to capture the human resource capacity development of Serang regency officials, implemented in 2012. The method used in this study is descriptive qualitative method, using the primary and secondary data. The results of the study demonstrates that the quality of human resources is still low, there are many positions in the organization structure are unfilled, the employee recruitment system is not based on job analysis, job position evaluation system have not been implemented, individual performance evaluation is not done according to competency based assessment, and employees have not received training according to their job position. It is recommended to perform system setup on recruitment; job analysis; Job evaluation; setting on job competency standard; competency based individual assessment; employee database development, and improvement on education and training curricula.
\end{abstract} Keywords: Human Resource, Development, Capacity.

\section{PENDAHULUAN}

Sejalan dengan diterapkannya sistem desentralisasi, dimana pemerintah memberikan kewenangan yang besar kepada daerah untuk menyelenggarakan berbagai urusan pemerintahan, dilakukan berbagai upaya untuk mengembangkan kapasitas pemerintah daerah dalam penyelenggaraan urusan pemerintahan melalui pengembangan kapasitas sumber daya manusia aparatur. Tujuannya adalah terciptanya pemerintahan daerah yang memiliki kapasitas yang berkelanjutan (sustainable) dalam penyelenggaraan pemerintahan, sehingga peningkatan kesejahteraan masyarakat dapat dicapai secara efektif dan efisien. Namun demikian, selama kurang lebih satu dasawarsa terakhir, upaya ini masih belum optimal guna mencapai hasil yang diharapkan.

Salah satu isu sentral good governance, yaitu adanya perubahan kapasitas pemerintah dalam merespon dan memperjuangkan kepentingan kolektif masyarakat berdasarkan koridor institusi yang ada (Keban, 2011). Dengan demikian, dapat juga berarti bahwa good governance harus didukung oleh dua aspek utama, yaitu masyarakat dan negara. Aspek yang pertama direpresentasikan oleh dua arena, masyarakat sipil dan masyarakat ekonomi. Masyarakat sipil berarti bahwa semua warga negara berhak mengontrol penyelenggaraan yang dilakukan pemerintah. Sementara aspek yang kedua 
direpresentasikan oleh birokrasi dan lembaga politik (political office). Aspek inilah yang menjadi kerap menjadi sorotan, terutama mengenai birokrasi yang didalamnya termasuk SDM aparatur.

Upaya pengembangan kapasitas sumber daya manusia (SDM) aparatur ini masih belum dapat dikelola dengan baik. Hal itu ditunjukkan antara lain oleh masih sulitnya mengubah cara pikir (mindset) dan cara kerja aparatur, masih rendahnya disiplin dan etika pegawai, sistem karier yang belum sepenuhnya berdasarkan prestasi kerja, sistem remunerasi yang belum memadai untuk hidup layak, rekrutmen yang belum dilakukan berdasarkan kualifikasi pendidikan yang dibutuhkan, penyelenggaraan pendidikan dan pelatihan (diklat) yang belum sepenuhnya dapat meningkatkan kinerja, lemahnya pengawasan dan audit terhadap kinerja aparatur, dan sistem informasi manajemen kepegawaian yang belum berfungsi secara optimal (Bappenas, 2007). Akibat dari berbagai persoalan tersebut adalah, pelaksanaan pelayanan publik yang efisien dan efektif, yaitu cepat, tepat, murah, dan transparan, belum dapat diwujudkan.

Siagian (1996) mengemukakan, bahwa rendahnya kinerja birokrasi disebabkan oleh beberapa sebab, seperti simpangsiurnya perundangundangan yang mengatur bidang kepegawaian; merajalelanya 'spoil system' dalam penerimaan, pengangkatan, penempatan dan promosi pegawai; tidak adanya data statistik yang akurat tentang jumlah pegawai negeri yang menimbulkan kesukaran dalam kebijaksanaan di bidang kepegawaian; sistem penilaian yang tidak obyektif; pendidikan dan pelatihan yang tidak terarah; banyaknya instansi yang turut campur tangan dalam memecahkan masalah kesejahteraan pegawai dan pendapatan pegawai negeri yang rendah, yang membawa implikasi pada rendahnya kegairahan kerja dan sukarnya menegakkan disiplin pegawai.

Oleh karena itu, dalam rangka meningkatkan kinerja pemerintah daerah, maka faktor pengembangan kapasitas aparatur menjadi sangat urgent. Di samping untuk merespon tingginya tuntutan masyarakat terhadap kinerja pemerintah daerah, pengembangan kapasitas (capacity building) SDM aparatur tidak bisa dilepaskan dengan keinginan pemerintah untuk menjalankan good governance yang diarahkan untuk mempraktekkan tata kelola pemerintahan yang ideal.

Pengembangan kapasitas SDM aparatur merupakan program andalan reformasi birokrasi dan telah mulai dilaksanakan sejak Pemerintahan Orde Baru berakhir, namun belum banyak membawa pengaruh. Pelaksanaannya dilatarbelakangi oleh berbagai faktor, di antaranya: tingginya praktek korupsi, kolusi dan nepotisme (KKN); tingkat kualitas pelayanan publik yang belum mampu memenuhi harapan publik; tingkat efisiensi, efektifitas dan produktivitas yang belum optimal; tingkat transparansi dan akuntabilitas yang masih rendah; serta tingkat disiplin dan etos kerja pegawai yang masih rendah.

Oleh karena itu, untuk percepatan pelaksanaan reformasi birokrasi di daerah, khususnya di Kabupaten Serang, perlu pengkajian mengenai potret SDM aparatur Pemda Kabupaten Serang, agar dapat dirumuskan model pengembangan kapasitas SDM aparatur di daerah.

Penelitian terdahulu yang membahas mengenai pengembangan kapasitas SDM, yakni oleh Siswanto (2006), dengan judul Studi Pengembangan Kapasitas Litbang Kesehatan di Daerah Provinsi Kalimantan Timur (Suatu Analisis Situasi). Penelitian ini bertujuan untuk melakukan analisis situasi dalam rangka mendapatkan base-line data tentang litbang di derah guna menyusun model fasilitasi pengembangan litbang di daerah dari aspek kelembagaan, sistem dan SDM. Hasilnya bahwa dari aspek kelembagaan, di tingkat propinsi sudah dibentuk Balitbangda, sementara pada tingkat kabupaten/kota belum semuanya. Selanjutnya, dari aspek jumlah SDM fungsional dan penganggaran di Balitbangda propinsi dan kabupaten/kota sangat terbatas. Perbedaan kajian ini dengan penelitian terdahulu adalah bahwa pada kajian ini lebih fokus pada SDM saja dan ruang lingkup yang lebih spesifik, yakni di kabupaten. Oleh karena itu, diharapkan kajian ini lebih fokus untuk mendapatkan temuan baru dibanding penelitian terdahulu.

Namun, pertanyaan pokok yang selalu muncul adalah, sampai seberapa besar keberhasilan pengembangan kapasitas aparatur itu di dalam mendukung reformasi birokrasi, khususnya di dalam pembangunan, pelaksanaan fungsi pemerintahan dan pemberian pelayanan publik. Faktanya dapat dilihat melalui media massa tentang kinerja pemerintahan yang selalu digambarkan sebagai ketidakmampuan, kelemahan, dan kejahatan dari berbagai pihak, mulai dari eksekutif, legislatif dan yudikatif.

Beberapa hal terkait kapabilitas sumber daya manusia dikemukakan oleh beberapa ahli sebagai berikut: Amstrong (2006) : salah satu sasaran yang dapat digunakan oleh para manajer dalam rangka melaksanakan investasi terhadap SDM di dalam organisasi adalah dengan melakukan pengembangan terhadap kapasitas SDM tersebut. Notoatmojo (dalam Suryanto, 2006) : pengembangan SDM aparatur sangat penting, karena dapat meningkatkan kemampuan aparatur, baik kemampuan profesionalnya, wawasannya, kepemimpinannya maupun pengabdiannya, sehingga pada akhirnya akan meningkatkan kinerja organisasi. Amri, Suryono \& Suwondo (2009) : tuntutan yang terasa kuat untuk melakukan pengembangan SDM, khususnya pada organisasi pemerintah disebabkan oleh: 1) tingkat pengetahuan dan kemampuan SDM masih relatif rendah; 2) suasana kerja yang kurang menyenangkan atau adanya kejenuhan karena terlalu lama bekerja pada suatu tempat; 3) adanya tuntutan organisasi terhadap perubahan; dan 4) perkembangan 
zaman yang sangat pesat. Siagian (1996) : beberapa alasan utama perlunya pengembangan SDM, yakni: 1) adanya pegawai baru yang tidak mempunyai kemampuan secara penuh untuk melaksanakan tugasnya; 2) pengetahuan pegawai yang perlu pemuktakhiran; 3) perubahan, tidak hanya karena perkembangan ilmu pengetahuan dan teknologi, akan tetapi juga karena pergeseran nilai-nilai sosial budaya; dan 4) kemungkinan perpindahan pegawai. Schuler dan Youngblood (dalam Eade, 1998) : pengembangan SDM aparatur pada suatu organisasi akan mencakup berbagai faktor, seperti diklat, perencanaan dan manajemen karir, peningkatan kualitas dan produktivitas kerja, serta peningkatan kesehatan dan keamanan kerja. Ivancevich (2002) : memasukkan pula faktor motivasi kerja dan penilaian prestasi kerja sebagai aspek yang tercakup dalam pengembangan SDM aparatur. Osborne dan Gaebler (dalam Eade, 1998) : lebih mementingkan pengembangan visi aparat pemerintah dalam memberikan pelayanan kepada publik. Hal itu sejalan dengan desentralisasi, pengembangan SDM aparatur yang perlu diarahkan pada pembentukan visi, inovasi, dan kemampuan aparat untuk melaksanakan semangat wirausaha dalam pelaksanana tugas mereka. CIDA (dalam Enemark, 2006): bahwa pengembangan SDM aparatur menekankan manusia sebagai alat maupun tujuan akhir pembangunan

Dalam jangka pendek, hal itu dapat diartikan sebagai pengembangan pendidikan dan pelatihan untuk memenuhi kebutuhan tenaga teknis, kepemimpinan, dan tenaga administrasi sesegera mungkin. Upaya ini ditujukan pada kelompok sasaran tertentu, yakni mereka yang terlibat dalam sistem sosial-ekonomi di negara tersebut. Emmeriji (dalam Calquit, 2006) : pengembangan SDM aparatur merupakan tindakan: a) kreasi SDM; b) pengembangannya; dan c) menyusun struktur insentif atau upah sesuai dengan peluang kerja yang ada. Luthans (2002) : ada 8 (delapan) tujuan pengembangan SDM aparatur, yaitu: 1) produktivitas personil organisasi (productivity); 2) kualitas produk organisasi (quality); 3) perencanaan SDM (human resources planning); 4) semangat personil dan iklim organisasi (morale); 5) meningkatkan kompensasi secara tidak langsung (indirect compensation); 6) kesehatan dan keselamatan kerja (health and safety); 7) pencegahan merosotnya kemampuan personil (absolerence prevention); dan 8) pertumbuhan kemampuan personil (personal growth). Steward (dalam Calquit, 2006): mengatakan bahwa modal intelektual merupakan kekayaan organisasi, karena modal intelektual adalah muatan intelektual yang dimiliki pegawai, yang berupa pengetahuan, informasi, hak pemilihan intelektual, pengalaman yang dapat digunakan untuk menciptakan kekayaan. Millen (2006): sebab pada dasarnya setiap anggota organisasi memiliki tujuan yang sama yaitu mencapai tujuan organisasi. Hersey and Blanchard
(1999): penyelenggaraan tugas pekerjaan administrasi negara yang semakin luas dan rumit menuntut kemampuan dan kemauan (ability and willingness) orang-orang untuk memikul tanggung jawab untuk mengarahkan perilaku mereka sendiri. Paling tidak terdapat tiga keterampilan yang perlu dimiliki setiap pegawai, sehingga proses manajemen, termasuk dibirokrasi dapat berlangsung secara rasional, efektif, dan efisien, yakni: keterampilan teknik, keterampilan kemanusiaan, dan keterampilan konseptual. Vroom (dalam Luthans, 2002) : rumusan $\mathrm{P}=\mathrm{C} \times \mathrm{M}$, yang artinya pelaksanaan tugas pekerjaan yang dapat memberikan buah hasil yang bermanfaat $(\mathrm{P}=$ performance $)$ hanya dapat dijamin apabila didukung oleh kemampuan $(\mathrm{C}=$ competence $)$ dan kemauan ( $\mathrm{M}=$ motivation) yang memadai.

Berdasarkan pandangan-pandangan di atas, dapat dikatakan bahwa pengembangan SDM aparatur dilakukan untuk menciptakan aparatur yang memiliki profesionalisme, yakni aparatur yang memiliki karakteristik: 1) seseorang yang memiliki keterampilan dan keahlian teoritis ilmiah tertentu sesuai dengan bidang pekerjaan yang akan digelutinya; 2) mampu menyumbangkan ilmu dan tenaganya secara optimal untuk kelancaran usaha tempat kerjanya; 3) dapat mendorong peningkatan produktivitas yang berkelanjutan; 4) memiliki sikap untuk terus menerus memperbaiki dan meningkatkan keahlian dan keterampilannya; 5) disiplin dan patuh aturan profesionalisme dan tempat kerjanya; dan 6) memiliki kesiapan untuk berubah atau melakukan penyesuaian terhadap perubahan-perubahan yang tengah berlangsung atau bahkan mampu menciptakan perubahan (Handayaningrat, 1995).

Pengembangan merupakan alat utama untuk menyesuaikan antara tugas dan pekerjaan dengan kemampuan, ketrampilan dan kecakapan serta keahlian dari setiap pegawai. Pengembangan juga merupakan faktor yang harus diselenggarakan dalam administrasi kepegawaian modern dan merupakan usaha untuk meningkatkan kinerja pegawai agar lebih cakap, trampil dan memahami dengan jelas tugas yang harus dilakukannya sesuai dengan kedudukannya sebagai seorang administrator.

Program-program pengembangan SDM yang diimplementasikan dalam bentuk off dan on the job misalnya tidak dilakukan dengan benar dan terkesan hanya sekedar menghabiskan anggaran yang tersedia, akibatnya dapat diduga bahwa peningkatan skill, knowledge dan ability sebagai tujuan utama yang harus diraih menjadi terdistorsi. Dengan demikian, kebijakan penyiapan SDM aparatur yang memiliki kinerja akan berkaitan dengan jenis dan sifat pengembangan yang akan dilakukan untuk memenuhi kebutuhan aparatur yang berkualitas.

Komponen pendukung. Reformasi birokrasi yang selama ini telah banyak dibahas dalam berbagai literatur administrasi publik, menggambarkan perubahan paradigma sekaligus perubahan struktur 
organisasi, manajemen, kebijakan, pola pikir dan budaya kerja.

Visi reformasi adalah terciptanya tata kelola pemerintahan yang baik, sedangkan misi reformasi tersebut adalah penyempurnaan peraturan perundang-undangan, modernisasi birokrasi melalui penggunaan IT, mengembangkan budaya, nilai-nilai kerja dan perilaku positif, restrukturisasi organisasi, peningkatan kualitas SDM, penyederhanaan sistem kerja, prosedur dan mekanisme kerja, dan mekanisme kontrol yang efektif. Adapun tujuannya adalah meningkatkan integritas birokrasi, meningkatkan produktivitas dan tanggung jawab dan memberikan pelayanan prima. Sasaran reformasi adalah: 1) kelembagaan, yaitu organisasi yang tepat fungsi dan tepat ukuran, 2) budaya organisasi, yaitu menghasilkan birokrasi dengan integritas dan kinerja yang tinggi, 3) ketatalaksanaan, yaitu sistem proses dan prosedur kerja yang jelas, efektif, efisien, terukur dan sesuai dengan prinsip good governance, 4) regulasi dan deregulasi birokrasi, yaitu terbentuknya regulasi yang tertib, tidak tumpang tindih dan kondusif, dan 5) sumber daya manusia, yaitu menghasilkan sumber daya manusia yang berintegritas, kompeten, profesional, berkinerja tinggi dan sejahtera.

Reformasi birokrasi telah dirintis mulai dari instansi pusat di beberapa kementerian, dan pada tahun 2012 ini diharapkan pemerintah daerah akan memulai proses didaerahnya, meskipun pada kenyataannya ada beberapa daerah yang telah melakukan reformasi birokrasi dengan baik.

Dari prinsip-prinsip yang dikemukakan kedua lembaga dunia tersebut, yang tidak kalah pentingnya adalah fisibilitas implementasi dari konsep-konsep itu di sektor pemerintah, khususnya pemerintah di daerah. Analisis atas fisibilitas tersebut penting dilakukan karena good governance harus lebih dimaknai sebagai sarana, dan bukan tujuan itu sendiri.

Pengembangan kapasitas merupakan pendekatan utama dalam pembangunan yang bertujuan memperkuat kemampuan manusia agar dapat menentukan sendiri apa yang berguna bagi dirinya dan prioritas hidupnya serta kemampuan mengorganisir diri untuk melakukan perubahan bagi masa depan (Eade, 1997:23). Alasan mendasar dari pengembangan kapasitas adalah karena manusia harus memiliki kemampuan bertahan hidup dan mengembangkan kehidupan yang layak sebagai manusia, berhak menikmati situasi dan lingkungan kondusif bagi kehidupan dan masa depannya serta berhak untuk hidup sejajar dan bebas berdampingan dengan manusia lain tanpa merasa terisolir, tertindas dan terdiskriminasikan oleh orang lain.

Fokus utama dari pengembangan kapasitas, menurut Eade (1997) adalah investing in people, in organization and in network. Investing in people mengandung makna bahwa manusia merupakan aktor yang harus mampu berbuat bagi kehidupan dan masa depannya; investing in organization dilakukan berdasarkan pertimbangan bahwa organisasi merupakan wadah atau alat yang digunakan manusia dalam mencapai tujuan bersama secara efisien dan efektif; sedangkan investing in network dimaksudkan sebagai akses yang digunakan manusia agar dapat berkomunikasi atau mendapatkan informasi yang dibutuhkan bagi kehidupan dan masa depannya. Pendapat ini serupa dengan Bank Dunia (Edralin, 1997) yang mencakup peningkatan kemampuan SDM, organisasi, dan jaringan kerja interaksi organisasi, sementara UNDP memusatkan perhatian pada kualitas SDM, modal dan teknologi.

Selain itu, Encyclopedia of Governance (Bevir, 2007) mendefenisikan pengembangan kapasitas, yakni: "Capacity building refers to those sets of activities in which vested parties (individuals, organizations, communities, or nation-states) develop the ability to effectively take part in governance. The underlying assumption is that by enhacing the appropriate skills, attitudes, and knowledge, these parties will be more effective in their respective governing roles. The result is a greater equalization of power, access to decisionmaking venues, and a more even distribution of society's benefits" (Bevir, 2007:66).

Dari uraian di atas, dapat disimpulkan bahwa pengembangan kapasitas tidak terlepas dari faktor pendukung lainnya. Hal itu terbukti bahwa sejak didengungkannya program pengembangan kapasitas menjelang tahun 2000, banyak instansi pemerintah berlomba untuk melaksanakannya dalam bentuk training, tetapi faktanya bahwa kinerja SDM aparatur masih rendah. Kajian ini bertujuan untuk mendeskripsikan kemampuan sumber daya manusia aparatur di daerah.

\section{METODE}

Kajian ini dilakukan dengan metode deskriptif kualitatif dengan tujuan untuk membuat gambaran secara sistematis, faktual dan akurat mengenai faktafakta dan sifat-sifat dan hubungan antara fenomena yang diselidiki. Data yang digunakan adalah data primer dari hasil wawancara yang melibatkan informan. Informan yang diwawancarai dalam kajian ini adalah kalangan Pemerintah Daerah Kabupaten Serang. Teknik snowball sampling juga digunakan ketika akses ke semua daftar informan yang diteliti tidak diperoleh. Jadi data yang digunakan adalah data kualitatif. Selain itu, ada data sekunder berupa dokumen resmi, laporan dan studi media juga digunakan. Selanjutnya, data yang diperoleh dianalisis secara teknik deskriptif kualitatif, yaitu dengan model interaktif dengan tahapan, yaitu melakukan reduksi data, sajian data dan penarikan kesimpulan. 


\section{HASIL DAN PEMBAHASAN}

Jumlah pegawai di Kabupaten Serang pada tahun 2012 adalah sebanyak 3.718 orang yang terdiri dari 1.441 orang laki-laki atau 38,76 persen dan 2.277 orang perempuan atau 61,24 persen. Gambaran mengenai komposisi pegawai berdasarkan kelompok umur di kabupaten Serang dapat dilihat pada Tabel 1.

Dilihat dari kelompok umurnya, sebagian besar pegawai di lingkungan pemerintah Kabupaten Serang berada pada usia produktif, yaitu usia 20-40 tahun. Jumlah pegawai usia tersebut adalah sebanyak 972 orang (26,14 persen). Sedangkan jumlah pegawai usia di atas 40 tahun adalah sebanyak 401 orang (10,79 persen).

Dilihat dari pendidikannya, sebagian besar pegawai di lingkungan pemerintah Kabupaten Serang berpendidikan SLTA, yakni sebanyak 1.216 orang (32,71 persen). Sedangkan yang berpendidikan di atas SLTA, termasuk sarjana hingga pasca sarjana adalah sebanyak 2.463 orang (66,25 persen). Gambaran komposisi pegawai berdasarkan tingkat pendidikannya dapat dilihat pada Tabel 2 .

Di Kabupaten Serang, masih terdapat pegawai yang berpendidikan SD dan SLTP, yakni masingmasing sebanyak 15 orang $(0,40$ persen $)$ dan 24 orang $(0,65$ persen $)$. Sedangkan pegawai yang berpendidikan pascasarjana strata 2 baru sebanyak 26 orang $(0,70$ persen $)$.

Berdasarkan jabatan yang diduduki, dari sebanyak 360 orang $(9,68$ persen $)$ pegawai menduduki jabatan struktural, sebanyak 2.653 orang (71,36 persen) menduduki jabatan fungsional khusus, dan sisanya, 705 orang (18,96 persen) menduduki jabatan fungsional umum. Hal itu dapat dilihat pada Tabel 3.

Dari jabatan struktural yang diduduki pegawai, sebanyak 195 orang (5,24 persen) menduduki jabatan struktural eselon IV a, sebanyak 68 orang ( 1,83 persen) menduduki jabatan eselon III b, 37 orang (1,00 persen) dengan jabatan eselon III a, eselon II b sebanyak 23 orang $(0,62$ persen) dan eselon II a $(0,01$ persen $)$ sebanyak 1 orang. Hal tersebut dapat dilihat apada Tabel 4.

Tabel 1. Komposisi Pegawai Berdasarkan Kelompok Umur Kabupaten Serang Tahun 2012

\begin{tabular}{clrrr}
\hline No & \multicolumn{1}{c}{ Kelompok Umur } & Laki-laki & Perempuan & Jumlah \\
\hline 1 & $<20$ tahun & - & - & - \\
2 & $20-29$ tahun & 102 & 270 & 372 \\
3 & $30-39$ tahun & 256 & 344 & 600 \\
4 & $40-49$ tahun & 110 & 95 & 205 \\
5 & $>50$ tahun & 149 & 47 & 196 \\
& Jumlah & $\mathbf{1 . 4 4 1}$ & $\mathbf{2 . 2 7 7}$ & $\mathbf{3 . 7 1 8}$ \\
\hline
\end{tabular}

Sumber: Badan Kepegawaian Daerah Kab.Serang, 2012

Tabel 2. Komposisi Pegawai Berdasarkan Tingkat Pendidikan Kabupaten Serang Tahun 2012

\begin{tabular}{clrrr}
\hline No & \multicolumn{1}{c}{ Tingkat Pendidikan } & Laki-laki & Perempuan & Jumlah \\
\hline 1 & Sekolah Dasar & 15 & 0 & 15 \\
2 & Sekolah Lanjutan Pertama & 20 & 4 & 24 \\
3 & Sekolah Lanjutan Atas & 423 & 793 & 1.216 \\
4 & Diploma I & 12 & 37 & 49 \\
5 & Diploma II & 122 & 270 & 392 \\
6 & Diploma III & 175 & 509 & 684 \\
7 & Sarjana S1 & 653 & 658 & 1.311 \\
8 & Pasca Sarjana S2 & 20 & 6 & 26 \\
9 & Pasca Sarjana S3 & 1 & - & 1 \\
& Jumlah & $\mathbf{1 . 4 4 1}$ & $\mathbf{2 . 2 7 7}$ & $\mathbf{3 . 7 1 8}$ \\
\hline
\end{tabular}

Sumber: Badan Kepegawaian Daerah Kab.Serang, 2012

Tabel 3. Komposisi Pegawai Berdasarkan Jabatan Kabupaten Serang Tahun 2012

\begin{tabular}{clrrr}
\hline No & \multicolumn{1}{c}{ Jabatan } & Laki-laki & Perempuan & \multicolumn{1}{c}{ Jumlah } \\
\hline 1 & Jabatan Struktural & 258 & 102 & 360 \\
2 & Jabatan Fungsional Khusus & 756 & 1.897 & 2.653 \\
3 & Jabatan Fungsional Umum & 424 & 281 & 705 \\
& Jumlah & $\mathbf{1 . 4 3 8}$ & $\mathbf{2 . 2 8 0}$ & $\mathbf{3 . 7 1 8}$ \\
\hline
\end{tabular}

Sumber: Badan Kepegawaian Daerah Kab.Serang, 2012 
Tabel 4. Komposisi Pegawai Berdasarkan Eselon Jabatan Struktural Kabupaten Serang Tahun 2012

\begin{tabular}{clc}
\hline No & \multicolumn{1}{c}{ Eselon } & Jumlah \\
\hline 1 & Eselon Ia & - \\
2 & Eselon Ib & - \\
3 & Eselon IIa & 1 \\
4 & Eselon IIb & 23 \\
3 & Eselon IIIa & 37 \\
4 & Eselon IIIb & 68 \\
5 & Eselon IVa & 195 \\
6 & Eselon IVb & - \\
7 & Eselon Va & - \\
8 & Eselon Vb & - \\
& Jumlah & $\mathbf{3 2 4}$ \\
\hline
\end{tabular}

Sumber: Badan Kepegawaian Daerah

Kab.Serang, 2012

Namun demikian, meskipun sebanyak 324 orang pegawai telah menduduki jabatan struktural, ternyata baru sebanyak 167 orang pegawai saja yang telah mengikuti diklat struktural. Ini berarti sebanyak 157 orang lainnya masih belum mengikuti diklat struktural yang dipersyaratkan untuk menduduki jabatan tersebut. Hal itu dapat dilihat pada Tabel 5.

Sedangkan pada jabatan fungsional, dari sebanyak 2.653 orang pegawai yang menduduki jabatan fungsional khusus, yang pernah mengikuti diklat adalah sebanyak 131 orang. Ini berarti sebanyak 2.522 orang lainnya menduduki jabatan fungsional khusus tanpa pernah mengikuti diklat.

Sementara itu, dilihat dari pengisian jabatan struktural dan diklat yang diikuti sebagai salah satu persyaratan untuk menduduki jabatan tersebut, dapat dilihat pada Tabel 6.

Berdasarkan pada Lampiran Tabel 6, dari sebanyak 38 jabatan struktural tingkat eselon II di Kabupaten Serang, baru sebanyak 35 jabatan yang telah diisi, sedangkan 3 jabatan lainnya belum terisi. Dari sebanyak 55 jabatan yang telah diisi tersebut, ternyata baru sebanyak 27 orang yang pejabatnya telah mengikuti diklat PIM II. Sementara itu, terdapat sebanyak 22 orang yang telah mengikuti diklat PIM II namun belum diangkat menjadi pejabat. Pada jabatan struktural tingkat eselon III, dari sebanyak 116 jabatan yang tersedia, sebanyak 109 jabatan di antaranya telah diisi, sedangkan 7 jabatan lainnya masih kosong (belum terisi). Dari sebanyak 109 jabatan yang terisi tersebut, baru sebanyak 46 orang pejabatnya yang telah mengikuti diklat PIM III, sedangkan 64 orang lainnya belum mengikuti diklat. Sedangkan pada jabatan struktural tingkat eselon IV, dari sebanyak 446 jabatan yang tersedia, baru terisi sebanyak 178 jabatan, sedangkan 201 jabatan lainnya belum terisi atau masih kosong. Dari jabatan yang telah terisi sebanyak 201, yang pejabatnya telah mengikuti diklat PIM IV adalah sebanyak 68 orang saja, sedangkan sebanyak 133 orang lainnya belum mengikuti diklat.
Berdasarkan deskripsi data tersebut, diperoleh temuan bahwa dari aspek kapasitas sumber daya manusia kondisi sumber daya manusia aparatur diindikasikan masih menghadapi berbagai masalah. Pertama, meskipun mayoritas pegawai berpendidikan SLTA keatas, namun jumlah pegawai berpendidikan pasca sarjana masih sangat sedikit dibandingkan dengan total jumlah pegawai. Kedua, tingkat pendidikan pegawai belum mampu mendukung pencapaian tupoksi organisasi perangkat daerah secara maksimal karena pembagian tugas pegawai belum dilakukan berdasarkan tingkat dan latar belakang pendidikan pegawai. Ketiga, meskipun gambaran jabatan pegawai lebih banyak yang menduduki jabatan fungsional dibandingkan dengan jabatan struktural, namun masih ada jabatan struktural yang kosong atau belum terisi. Hal ini di samping terkait dengan kapasitas pegawai, juga terkait dengan masih belum mampunya program pelatihan/diklat pegawai (baik struktural maupun fungsional) yang dilaksanakan untuk mengatasi kebutuhan pegawai secara keseluruhan. Keempat, dari sisi kompetensi pegawai, kompetensi pegawai yang ada saat ini belum sesuai dengan tuntutan kinerja organisasi. Usia, tingkat pendidikan, dan pangkat/golongan ternyata belum mencerminkan kompetensi pegawai. Kelima, sistem rekrutmen meskipun cukup baik namun belum mampu menjaring pegawai yang lebih berkualitas sehingga menghasilkan personil yang lebih memiliki kapabilitas. Keenam, rekrutmen pegawai belum didasarkan pada analisis jabatan dalam organisasi guna untuk mendukung tercapainya tupoksi. Ketujuh, evaluasi jabatan dalam organisasi perangkat daerah belum semua dilakukan. Demikian pula, penyusunan standar kompetensi jabatan belum dilakukan untuk mendapatkan individu yang sesuai dengan kualifikasi dari jabatan tersebut. Kedelapan, asesmen penilaian kinerja individu berdasarkan kompetensi belum dilakukan. Kesembilan, pengembangan database pegawai meskipun sudah dilakukan namun belum mampu sepenuhnya menghasilkan informasi yang cepat, tepat, dan akurat. Kesepuluh, pengembangan pendidikan dan pelatihan pegawai berbasis kompetensi meskipun telah dilakukan, namun hal itu masih belum mampu meningkatkan kemampuan individu aparatur pemerintah secara maksimal sesuai dengan tuntutan pekerjaan. Kesebelas, pegawai-pegawai yang memiliki jabatan struktural maupun fungsional sebagian besar masih belum pernah mendapatkan diklat yang sesuai dengan jabatannya.

Temuan tersebut menunjukkan bahwa masih terdapat berbagai permasalahan mengenai pengelolaan pegawai yang dilakukan selama ini. Hal tersebut juga menunjukkan bahwa meskipun manajemen pembinaan pegawai pada umumnya telah merujuk pada UU No. 43 Tahun 1999 beserta peraturan pelaksanaannya serta UU No 32 Tahun 2004 tentang Pemerintahan Daerah, namun 
Tabel 5. Komposisi Pegawai Berdasarkan Diklat Yang Diikuti Kabupaten Serang Tahun 2012

\begin{tabular}{|c|c|c|c|c|c|}
\hline \multirow{3}{*}{ No. } & \multirow{3}{*}{ SKPD } & \multicolumn{4}{|c|}{ Jumlah Pegawai yang mengikuti Diklat } \\
\hline & & \multicolumn{2}{|c|}{ Struktural } & \multicolumn{2}{|c|}{ Fungsional } \\
\hline & & $\mathbf{L k}$ & Pr & Lk & Pr \\
\hline 1 & SEKRETARIAT DAERAH & 20 & 5 & 8 & 1 \\
\hline 2 & STAF AHLI BUPATI & 2 & 2 & 0 & 0 \\
\hline 3 & SEKRETARIAT DPRD & 5 & 1 & 0 & 0 \\
\hline 4 & BAPPEDA & 3 & 0 & 0 & 0 \\
\hline 5 & $\begin{array}{l}\text { BADAN KEPEGAWAIAN DAERAH DAN DIKLAT } \\
\text { BADAN KELUARGA BERENCANA DAN }\end{array}$ & 6 & 0 & 1 & 2 \\
\hline 6 & $\begin{array}{l}\text { PEMBERDAYAAN PEREMPUAN } \\
\text { BADAN PENYULUHAN DAN KETAHANAN }\end{array}$ & 1 & 1 & 2 & 12 \\
\hline 7 & $\begin{array}{l}\text { PANGAN } \\
\text { BADAN PEMBERDAYAAN MASYARAKAT DAN }\end{array}$ & 5 & 3 & 16 & 7 \\
\hline 8 & PEMERINTAHAN DESA & 4 & 4 & 4 & 0 \\
\hline 9 & BADAN ARSIP DAN PERPUSTAKAAN DAERAH & 1 & 1 & 9 & 9 \\
\hline 10 & DINAS PEKERJAAN UMUM & 3 & 1 & 0 & 0 \\
\hline 11 & $\begin{array}{l}\text { BADAN KESBANGPOL LINMAS DAN POL. PP } \\
\text { DINAS PENGELOLAAN KEUANGAN DAN ASET }\end{array}$ & 2 & 0 & 0 & 0 \\
\hline 12 & DAERAH & 5 & 1 & 4 & 0 \\
\hline 13 & DINAS PENDIDIKAN & 3 & 1 & 1 & 0 \\
\hline 14 & DINAS TENAGA KERJA DAN TRANSMIGRASI & 4 & 0 & 3 & 1 \\
\hline 15 & DINAS PERTANIAN & 9 & 2 & 0 & 0 \\
\hline 16 & DINAS SOSIAL & 4 & 0 & 3 & 1 \\
\hline 17 & $\begin{array}{l}\text { DINAS PERHUBUNGAN } \\
\text { DINAS KEPENDUDUKAN DAN PENCATATAN }\end{array}$ & 5 & 1 & 6 & 2 \\
\hline 18 & ( & 1 & 0 & 0 & 0 \\
\hline 19 & DINAS PERIKANAN DAN KELAUTAN & 9 & 2 & 0 & 0 \\
\hline 20 & DINAS PERINDUSTRIAN DAN PERDAGANGAN & 7 & 2 & 9 & 1 \\
\hline 21 & DINAS KOPERASI DAN UMKM & 7 & 2 & 9 & 1 \\
\hline 22 & INSPEKTORAT DAERAH & 4 & 0 & 5 & 0 \\
\hline 23 & $\begin{array}{l}\text { DINAS PERTAMBANGAN DAN ENERGI } \\
\text { DINAS PEMUDA DAN OLAH RAGA, }\end{array}$ & 0 & 0 & 0 & 0 \\
\hline 24 & KEBUDAYAAN DAN PARIWISATA & 4 & 0 & 3 & 1 \\
\hline 25 & DINAS TATA RUANG & 8 & 1 & 5 & 0 \\
\hline 26 & DINAS PENGELOLAAN LINGKUNGAN HIDUP & 5 & 0 & 2 & 0 \\
\hline 27 & DINAS KESEHATAN & 3 & 2 & 0 & 3 \\
\hline 28 & KANTOR PEMADAM KEBAKARAN & 0 & 0 & 0 & 0 \\
\hline 29 & AKADEMI PERAWAT & 0 & 0 & 0 & 0 \\
\hline 30 & KANTOR PELAYANAN TERPADU SATU PINTU & 0 & 0 & 0 & 0 \\
\hline 31 & RUMAH SAKIT UMUM & 3 & 2 & 0 & 0 \\
\hline 32 & KECAMATAN & 0 & 0 & 0 & 0 \\
\hline 33 & DESA & 0 & 0 & 0 & 0 \\
\hline 34 & SEKRETARIAT KPUD & 0 & 0 & 0 & 0 \\
\hline 35 & SEKRETARIAT KORPRI & 0 & 0 & 0 & 0 \\
\hline & Jumlah & 133 & 34 & 90 & 41 \\
\hline
\end{tabular}

Sumber: Badan Kepegawaian Daerah Kab.Serang, 2012

implementasi undang-undang tersebut di lapangan mengindikasikan berbagai permasalahan yang kompleks sejak dari peraturan perundang-undangan hingga ke pengelolaan pegawai.

Dari perspektif sistem dan peraturan perundang-undangan, sistem kebijakan dan peraturan perundang-undangan yang mengatur manajemen PNS selama ini sudah cukup baik, namun yang menjadi penyebab kurang profesionalnya pegawai adalah pada implementasi peraturan perundangundangan tersebut. Misalnya, promosi dan mutasi pegawai yang seharusnya dilakukan secara transparan sebagai bentuk penghargaan dan tour of duty, dalam kenyataannya sering dilakukan secara sembunyi-sembunyi dan bermuatan politis. Manajemen pegawai daerah yang diatur dalam UU No. 32 Tahun 2004 dinilai bernuansa sentralisasi. Selain itu, diantara pemerintah pusat sendiri 
Tabel 6. Komposisi Pegawai Berdasarkan Pengisian Jabatan Struktural dan Diklat Kabupaten Serang 2012

\begin{tabular}{|c|c|c|c|c|c|c|c|c|c|c|c|c|c|c|c|c|}
\hline \multirow{3}{*}{ No } & \multirow{3}{*}{ SKPD } & \multicolumn{5}{|c|}{ ESELON II } & \multicolumn{5}{|c|}{ ESELON III } & \multicolumn{5}{|c|}{ ESELON IV } \\
\hline & & \multirow[b]{2}{*}{ Jlh } & \multirow[b]{2}{*}{ Trs } & \multirow[b]{2}{*}{ Low } & \multirow{2}{*}{$\begin{array}{c}\text { Sdh } \\
\text { Diklat } \\
\text { PIM } \\
\text { II }\end{array}$} & \multirow[b]{2}{*}{$\underset{\text { Diklat }}{\text { Blm }}$} & \multirow[b]{2}{*}{ Jlh } & \multirow[b]{2}{*}{ Trs } & \multirow[b]{2}{*}{ Low } & \multirow{2}{*}{$\begin{array}{l}\text { Sdh } \\
\text { Dilkat } \\
\text { PIM } \\
\text { III }\end{array}$} & \multirow[b]{2}{*}{$\underset{\text { Diklat }}{\text { Blm }}$} & \multirow[b]{2}{*}{ Jlh } & \multirow[b]{2}{*}{ Trs } & \multirow{2}{*}{\multicolumn{2}{|c|}{$\begin{array}{cc} & \text { Sdh } \\
& \text { Diklat } \\
\text { Low } & \text { PIM } \\
& \text { IV }\end{array}$}} & \multirow[b]{2}{*}{$\begin{array}{c}\text { Blm } \\
\text { Diklat }\end{array}$} \\
\hline & & & & & & & & & & & & & & & & \\
\hline 1 & Sekretariat Daerah & 9 & 8 & 1 & 5 & 3 & 10 & 6 & 4 & 5 & 1 & 27 & 16 & 11 & 8 & 8 \\
\hline 2 & Staf Ahli Bupati & 2 & 2 & 0 & 2 & 1 & 1 & 1 & 1 & 1 & 1 & 1 & 1 & 1 & 1 & 1 \\
\hline 3 & Sekretariat DPRD & 1 & 1 & 0 & 0 & 1 & 3 & 3 & 0 & 1 & 2 & 7 & 5 & 2 & 2 & 3 \\
\hline 4 & BAPPEDA & 1 & 0 & 1 & 0 & 0 & 5 & 4 & 1 & 1 & 3 & 11 & 5 & 6 & 3 & 2 \\
\hline 5 & BKD dan Diklat & 1 & 1 & 0 & 1 & 0 & 4 & 3 & 1 & 2 & 1 & 9 & 4 & 5 & 1 & 3 \\
\hline 6 & $\begin{array}{l}\text { Badan KB \& } \\
\text { Pemberd. Pr }\end{array}$ & 1 & 1 & 0 & 1 & 0 & 1 & 1 & 0 & 0 & 1 & 4 & 2 & 2 & 1 & 1 \\
\hline 7 & BPKP & 1 & 1 & 0 & 1 & 0 & 5 & 3 & 2 & 1 & 2 & 29 & 13 & 16 & 5 & 8 \\
\hline 8 & $\begin{array}{l}\text { BPM dan Pem. } \\
\text { Des }\end{array}$ & 1 & 1 & 0 & 1 & 1 & 4 & 4 & 0 & 2 & 2 & 9 & 4 & 5 & 1 & 3 \\
\hline 9 & $\begin{array}{l}\text { Badan Arsip dan } \\
\text { Perpusda }\end{array}$ & 1 & 1 & 0 & 1 & 1 & 1 & 1 & 0 & 1 & 1 & 1 & 1 & 1 & 1 & 1 \\
\hline 10 & DPU & 1 & 0 & 1 & 1 & 1 & 4 & 1 & 3 & 1 & 0 & 10 & 7 & 3 & 4 & 3 \\
\hline 11 & $\begin{array}{l}\text { BaKesBangLinmas } \\
\text { \& Pol. PP }\end{array}$ & 1 & 1 & 0 & 1 & 1 & 1 & 1 & 0 & 1 & 0 & 3 & 2 & 1 & 1 & 1 \\
\hline 12 & DPKAD & 1 & 1 & 0 & 1 & 0 & 5 & 5 & 0 & 3 & 2 & 25 & 8 & 17 & 3 & 5 \\
\hline 13 & Dinas Pendidikan & 1 & 1 & 0 & 1 & 0 & 5 & 5 & 0 & 2 & 3 & 31 & 20 & 11 & 1 & 19 \\
\hline 14 & Disnakertrans & 1 & 1 & 0 & 1 & 1 & 1 & 1 & 0 & 2 & 4 & 17 & 5 & 12 & 2 & 3 \\
\hline 15 & Dispertan & 1 & 1 & 0 & 1 & 1 & 5 & 5 & 0 & 3 & 2 & 23 & 11 & 12 & 5 & 6 \\
\hline 16 & Dinsos & 1 & 1 & 0 & 0 & 0 & 6 & 6 & 0 & 2 & 4 & 17 & 5 & 12 & 2 & 3 \\
\hline 17 & Dishub & 1 & 1 & 0 & 0 & 0 & 4 & 4 & 0 & 1 & 3 & 17 & 4 & 13 & 3 & 1 \\
\hline 18 & Disdukcapil & 1 & 1 & 0 & 1 & 1 & 4 & 4 & 0 & 1 & 3 & 10 & 5 & 5 & 0 & 5 \\
\hline 19 & $\begin{array}{l}\text { Dis. Perikanan dan } \\
\text { Kelautan }\end{array}$ & 1 & 1 & 0 & 1 & 1 & 5 & 5 & 0 & 3 & 2 & 23 & 11 & 12 & 5 & 6 \\
\hline 20 & Disperindag & 1 & 1 & 0 & 1 & 1 & 5 & 5 & 0 & 1 & 4 & 12 & 9 & 3 & 4 & 5 \\
\hline 21 & $\begin{array}{l}\text { Diskop dan } \\
\text { UMKM }\end{array}$ & 1 & 1 & 0 & 1 & 1 & 5 & 5 & 0 & 1 & 4 & 12 & 9 & 3 & 4 & 5 \\
\hline 22 & Insp. Daerah & 1 & 1 & 0 & 0 & 1 & 4 & 4 & 0 & 3 & 1 & 12 & 2 & 10 & 0 & 2 \\
\hline 23 & Dispertamben & 1 & 1 & 0 & 1 & 0 & 1 & 1 & 0 & 1 & 1 & 1 & 1 & 1 & 1 & 1 \\
\hline 24 & Disporbudpar & 1 & 1 & 0 & 0 & 1 & 6 & 6 & 0 & 2 & 4 & 17 & 5 & 12 & 2 & 3 \\
\hline 25 & Dia. Tata Ruang & 1 & 1 & 0 & 1 & 1 & 5 & 5 & 0 & 3 & 2 & 11 & 8 & 3 & 2 & 6 \\
\hline 26 & DPLH & 1 & 1 & 0 & 1 & 1 & 4 & 4 & 0 & 1 & 3 & 11 & 4 & 7 & 3 & 1 \\
\hline 27 & Dinkes & 1 & 1 & 0 & 1 & 1 & 5 & 4 & 1 & 1 & 3 & 37 & 22 & 15 & 1 & 21 \\
\hline 28 & Kantor Damkar & & & & & & & & & & & & & & & \\
\hline 29 & Akper & & & & & & & & & & & & & & & \\
\hline 30 & KPT & & & & & & & & & & & & & & & \\
\hline 31 & RSU & & & & & & 5 & 5 & 0 & 0 & 5 & 9 & 9 & 0 & 2 & 7 \\
\hline 32 & KECAMATAN & & & & & & & & & & & & & & & \\
\hline 33 & DESA & & & & & & & & & & & & & & & \\
\hline 34 & SEK. KPUD & 1 & 1 & 0 & 1 & 1 & 1 & 1 & 0 & 0 & 0 & 0 & 0 & 0 & 0 & 0 \\
\hline 35 & SEK. KORPRI & 1 & 1 & 0 & 1 & 1 & 1 & 1 & 0 & 0 & 0 & 0 & 0 & 0 & 0 & 0 \\
\hline & JUMLAH & 38 & 35 & 3 & 27 & 22 & 116 & 109 & 7 & 46 & 64 & 446 & 178 & 201 & 68 & 133 \\
\hline
\end{tabular}

Sumber: Badan Kepegawaian Daerah Kab.Serang, 2012.

(Kementerian PAN dan BKN) koordinasi mengenai penetapan formasi PNS masih lemah. Peraturan tentang penggajian juga dinilai memiliki kelemahan karena gaji yang diberikan kepada pegawai kurang mampu memenuhi kebutuhan hidup layak. Di samping itu, gaji yang diberikan kepada pegawai hanya didasarkan pada golongan pangkat/ruang dan masa kerja serta tidak mempertimbangkan kinerja yang dicapai oleh pegawai. Pejabat pembina kepegawaian yang dijabat oleh kepala daerah yang merupakan pejabat politis, sewaktu-waktu dapat menimbulkan permasalahan bagi pegawai karena secara tidak langsung sering terkait dengan isu-isu politik.

Persoalan lain, aturan-aturan yang terdapat dalam PP No. 30 Tahun 1980 ternyata sangat longgar dalam law enforcement-nya. Pertama, aturan hukum ini mengatur kehidupan PNS termasuk yang tidak berkaitan langsung dengan pelaksanaan tugasnya. Kedua, pelanggaran disiplin terlalu diakomodir dan hukuman yang diberikan sangat lunak. Ketiga, dalam praktiknya aturan-aturan dalam PP No. 30 Tahun 1980 ini seringkali tidak berjalan secara efektif di lapangan baik disebabkan oleh individu PNS itu yang tidak mematuhi peraturan tersebut maupun oleh pimpinan yang tidak tegas menegakkan aturan. PNS yang akan mengikuti suatu diklat tidak didasarkan pada training needs assessment (TNA) untuk mengetahui competency gap. Disain kurikulum dan program pendidikan dan pelatihan yang diikuti oleh PNS harus mampu memperkecil competency gap tersebut. Dalam hal ini, pendekatan pendidikan dan 
pelatihan merupakan competence-besed training. Namun dalam kenyataannya, tidak semua lembaga pendidikan dan pelatihan PNS mengikuti pendekatan atau metode ini. Bahkan pengiriman PNS ke pendidikan dan pelatihan dalam rangka menduduki jabatan sering terjadi tidak terkait dengan pengembangan kariernya. Hal ini tentu sangat boros sebagai akibat diabaikannya training needs assessment.

Secara lebih mikro, permasalahan penyelenggaraan kepegawaian daerah menyangkut seluruh sistem manajemen sumber daya aparatur daerah sejak dari perencanaan, pengadaan, sampai pensiun.

Dari sisi perencanaan, hingga saat ini belum terdapat perencanaan kebutuhan pegawai yang jelas dan rinci. Umumnya pemerintah daerah belum memiliki peta kebutuhan pegawai (semacam manpower planning), paling tidak untuk lima tahun ke depan. Proses rekrutmen selama ini, pemerintah daerah mengajukan usulan kebutuhan pegawai ke pemerintah pusat, namun pemerintah daerah belum menghitung secara sangat cermat mengenai jumlah dan kualifikasi pegawai yang dibutuhkan, ketersediaan anggaran untuk gaji dan tunjangan, serta mempertimbangkan kelebihan pegawai dan/atau tenaga honorer. Perencanaan kebutuhan pegawai hanya didasarkan pada usulan yang diajukan oleh masing-masing unit kerja kepada bagian kepegawaian untuk diteruskan oleh kepala daerah kepada Kementerian PAN untuk mendapatkan penetapan formasi. Perencanaan yang seperti ini hanya bersifat jangka pendek dari tahun ke tahun, sehingga tidak dapat memetakan kebutuhan secara menyeluruh terhadap kebutuhan pegawai baik kualifikasi pendidikan, keahlian, jumlah, distribusi menurut instansi dan kriteria-kriteria lain sesuai kebutuhan pembangunan dan visi/misi daerah.

Dari sisi beban kerja, secara umum beban kerja mayoritas pegawai belum optimal karena porsi pekerjaan yang diselesaikan oleh pegawai masih berada di bawah kapasitas optimal yang seharusnya. Terdapat pengangguran tidak kentara di lingkungan pemerintah daerah karena beban kerja pegawai yang tidak sepadan dengan jumlah pegawai yang ada. Akibatnya, pekerjaan yang seharusnya dapat dilakukan oleh dua atau tiga orang, kenyataannya dilakukan secara gotong royong oleh empat orang atau lebih. Pada sisi lain, pegawai yang good performer ini biasanya 'dipakai' oleh pimpinan, sedangkan yang bad performer cenderung kurang dipercaya untuk menyelesaikan pekerjaan-pekerjaan yang berat dan serius. Akibatnya, kelompok ini akan mengalami under employment sehingga 'luntanglantung' di unit kerjanya. Beban kerja pegawai yang tidak seimbang ini pada dasarnya disebabkan oleh tidak tersedianya uraian tugas (job description) pada saat mereka diterima menjadi calon pegawai.

Dari sisi pola karier, sampai saat ini, pegawai di Indonesia belum memiliki peraturan perundang- undangan yang mengatur tentang pola karier pegawai. Padahal pola karier pegawai sangat penting sebagai dasar pengembangan karier dan potensi pegawai sehingga pengangkatan pegawai dalam suatu jabatan struktural dapat dilakukan secara adil dan transparan. Jika pola karier telah terwujud, maka seorang pegawai dapat mengetahui arah perjalanan dan bahkan merencanakan kariernya serta jabatan yang akan diembannya sesuai kompetensi yang dimiliki selama jangka waktu tertentu, misalnya sepuluh tahun ke depan. Kondisi pola karier aparatur pemerintah saat ini belum didasarkan pada standar kompetensi baik persyaratan umum, persyaratan manajerial, dan persyaratan teknis, sehingga berdampak kurang positif terhadap kinerja instansinya. Sistem kenaikan pangkat yang diberlakukan selama ini masih bersifat administrasi dan masih belum dikaitkan dengan prestasi kerja yang dihasilkan pegawai. Penyebab lainnya adalah kelemahan sistem pengukuran kinerja sehingga pegawai yang berprestasi kurang mendapat perhatian dan penghargaan yang adil. Pegawai yang prestasi kerjanya tidak bagus masih memungkinkan untuk naik pangkat/golongan. Kendala yang terjadi adalah ketidaksesuaian antara kompetensi dengan pekerjaan yang diemban. Permasalahan ini muncul antara lain disebabkan pada saat rekruitmen, kebutuhan yang diinginkan oleh pemerintah daerah tidak sesuai dengan lowongan pekerjaaan yang ada. Hal yang lain, pengembangan jabatan fungsional masih selalu diabaikan oleh pemerintah daerah, padahal melalui jabatan fungsional dapat dikembangkan profesionalisme aparatur.

Persoalan lainnya menyangkut mutasipromosi pegawai terkait dengan pengangkatan dalam jabatan struktural yang sangat kental dengan nuansa politik lokal. Dari sisi promosi, promosi pegawai ke dalam jabatan struktural belum didasarkan pada kinerja pegawai yang bersangkutan. Promosi pejabat struktural masih dilakukan dengan cara 'dukungmendukung'. Fenomena ini muncul karena besarnya otoritas kepala daerah dalam pengelolaan kepegawaian di daerah. Fungsi Badan Pertimbangan Jabatan dan Kepangkatan (Baperjakat) sendiri juga kurang efektif karena Ketua Baperjakat dijabat langsung oleh Bupati. Dengan demikian, kepentingan politis juga sering mendominasi proses promosi pejabat struktural di daerah. Akibatnya, sangat sulit memperoleh pejabat struktural yang kompeten dan profesional di bidangnya karena pengangkatan dan keberadaan pejabat yang diangkat hanya untuk melayani penguasa (pejabat negara pada daerah yang bersangkutan). Hal ini juga banyak terjadi pada daerah-daerah lain yang sulit dihindari dan dikontrol.

Dari sisi mutasi, terdapat permasalahan mengenai obyektivitas pemerintah daerah dalam penempatan pegawai sesuai dengan kompetensi dasar dan bidang masing-masing pegawai. Masih sedikit jumlah pemerintah daerah yang secara serius 
melakukan tes kelayakan dan kepatutan (fit and proper test) dalam rangka penempatan ataupun promosi pegawai. Proses mutasi khususnya dalam pengertian perpindahan pegawai antar unit kerja di lingkungan pemerintah daerah yang sama, juga memperlihatkan kondisi yang belum terpola dengan mekanisme yang jelas, adil dan transparan, dan kurang terencana. Hasilnya, dapat dikatakan bahwa prinsip 'the right man in the right place on the right time' masih sebatas slogan karena adanya muatan kepentingan dari pejabat tertentu yang mempunyai kewenangan di bidang kepegawaian ataupun ada interest pribadi yang sangat kuat terhadap jabatan atau orang yang dipromosikan. Oleh sebab itu pola mutasi atau aturan main dalam mutasi tidak dapat terwujud.

Dari sisi pengukuran kinerja, sistem dan implementasi pengukuran kinerja pegawai yang masih berlaku dewasa ini menempati posisi yang sangat strategis karena pada dasarnya hasil pengukuran kinerja yang dilakukan secara objektif, valid dan terukur memberikan banyak manfaat bagi proses pengambilan keputusan di bidang kepegawaian. Namun hal ini kurang disadari oleh para pengambil kebijakan di bidang pengelolaan kepegawaian. Penilaian pegawai yang berlaku sampai saat ini pada dasarnya tidak memiliki arti yang nyata terhadap pengukuran kinerja pegawai. Penilaian tersebut sangat subyektif karena kelemahan-kelemahan aspek, mekanisme dan sifat pengukurannya. Hasil penilaian tersebut tidak dapat membedakan seorang pegawai yang mempunyai kinerja yang bagus dengan yang tidak bagus. Yang anehnya, tidak ada satupun dari atasan yang berkeinginan untuk memberikan penilaian yang jelek terhadap anak buahnya sekalipun faktanya memang kinerja bawahannya tidak memuaskan.

Dari sisi remunerasi, remunerasi atau penggajian kepada pegawai pada semua tingkatan masih belum mampu membuat pegawai sejahtera. Persoalan minimnya gaji/tunjangan yang diterima pegawai selama ini menjadi alasan tidak mampunya pegawai menunjukkan kinerja yang tinggi. Minimnya gaji pegawai merupakan masalah klasik yang sampai dewasa ini tetap tidak mampu menopang kehidupan yang layak dan sejahtera. Sebagian besar pegawai melaksanakan pekerjaan sampingan di luar jam kantor untuk mendapatkan tambahan penghasilan. Adakalanya, pekerjaan sampingan tersebut juga dilakukan pada jam kantor.

Sedangkan dari sisi pendidikan dan pelatihan, terdapat sejumlah permasalahan pendidikan dan pelatihan pegawai yang dilakukan selama ini. Beberapa kelemahan pola diklat yang ada antara lain, adalah: 1). Saat ini sistem pelatihan yang ada baru terfokus pada diklat penjenjangan, diklat fungsional dan diklat teknis yang belum tertangani dengan baik dan saat ini masih dalam taraf perbaikan menyeluruh. 2). Training needs belum dapat dimanfaatkan untuk menghasilkan pola diklat yang sistemik dan berbasis kompetensi. 3). Desain pelatihan, kurikulum dan jam pelatihan belum mengacu pada standar kompetensi yang dibutuhkan. 4). Spesialisasi Instruktur dan Widyaiswara masih terfokus pada aspek manajemen. 5). Diklat belum mempertimbangkan kesesuaian antara kompetensi pegawai dengan kompetensi yang dipersyaratkan oleh jabatan yang akan datang. Untuk itu perlu disiapkan pola diklat yang dapat mendukung pola karir pegawai.

Di samping itu, pelaksanaan pendidikan dan pelatihan selama ini sangat monoton, terutama dari segi substansi materi diklat. Sebagian besar materi Diklatpim Tingkat IV dan Diklatpim Tingkat III hampir sama. Di lingkungan pemerintah daerah, keterbatasan anggaran merupakan salah satu kendala utama dalam penyelenggaraan pendidikan dan pelatihan PNS. Oleh karena itu, agar lebih efektif, maka peserta Diklatpim sebaiknya duduk dulu dalam jabatan yang baru sebelum mengikuti Diklatpim.

\section{KESIMPULAN}

Dari uraian di atas, potret SDM aparatur di Pemda Kabupaten Serang adalah masih berkualitas rendah, masih ada jabatan struktural yang belum terisi, rekrutmen pegawai belum berdasarkan pada analisis jabatan, evaluasi jabatan belum dilakukan, penilaian kinerja individu berdasarkan kompetensi belum dilakukan, dan kurikulum diklat belum mampu meningkatkan kemampuan sesuai dengan tuntutan pekerjaan.

Oleh karena itu, perlu penataan sistem rekrutmen pegawai; analisis jabatan; evaluasi jabatan; penyusunan standar kompetensi jabatan; penilaian individu berdasarkan kompetensi; pembangunan database pegawai; dan perbaikan kurikulum diklat. 


\section{Daftar Pustaka}

Amri, Agus Suryono dan Suwondo, 2009 Pengembangan Sumberdaya Aparatur Sebagai Upaya Meningkatkan Kinerja: Studi di Kantor Sekretariat Daerah Kabupaten Sumbawa, WACANA, Vol. 12 No.3 Juli 2009.

Armstrong, Michael, 2006. A Handbook of Human Resource Management Practice, London, Philadelphia: Kogan Page.

Colquit, Jason A., Jeffery A. LePine \& Michael J. Wesson, 2009. Organizational Behavior: Improving Performance and Commitmen in the Workplace, New York: McGraw-HillIrwin.

Eade, D., 1998, Capacity Building: An Approach to People-Centered Development, Oxford, UK: Oxfam, GB.

Edralin, J.S1, 1997. The New Local Governance and Capacity Building: A Strategic Approach, Regional Development Studies, Vol.3, p.148150.

Enemark, Stig, 2006. Capacity Building for Institutional Development in Surveying and Land Management, paper presented in the Promoting Land Administration and Good Governance, 5th FIG Regional Conference Accra, Ghana, March 8-11, 2006.

Hanif, Nurcholis, 2005. Pengembangan Kapasitas Pemda: Upaya Mewujudkan Pemda yang Menyejahterakan Masyarakat, Jurnal
Organisasi dan Manajemen, Voume. 1, Nomor 1, September 2005.

Hersey, P. and K. H. Blanchard, 1999. Leadership and the One Minute Manager, New York: William Morrow.

Ivancevich, John M. and Michael T. Matteson, 2002. Organizational Bahavior and Management, Boston: McGraw-Hill

Keban, Yeremias T., 2011, Menuju Sistem Ketatalaksanaan Pemerintahan Yang Baik, bahan presentase pada Diklatpim I Angkatan XXII LAN RI, 30 September 2011.

Luthans, Fred, 2002. Organizational Behavior, Boston: McGraw-Hill-Irwin

Milen A. 2006. Capacity Building: Meningkatkan Kinerja Sektor Publik. Yogyakarta: Pembaruan.

Siagian, Sondang P., 1996. Manajemen Sumber Daya Manusia, Jakarta: CV. Haji Masagung

Siswanto, 2006. Studi Pengembangan Kapasitas Litbang Kesehatan di Daerah Provinsi Kalimantan Timur (Suatu Analisis Situasi), Balitbang Depkes, Jakarta.

Soeprapto, Riyadi, 2007. Pengembangan Kapasitas Pemerintah Daerah Menuju Good Governance, Jakarta: PT Gunung Agung.

Suryanto, 2006. Reformasi Kebijakan Pelaksanaan Administrasi Pemerintahan Daerah, Jurnal Desentralisasi Vol. 7 No.4 Tahun 2006. http://www.bappenas.go.id/get-file-server/node/6167/ diunduh tanggal 14 Agustus 2012 
